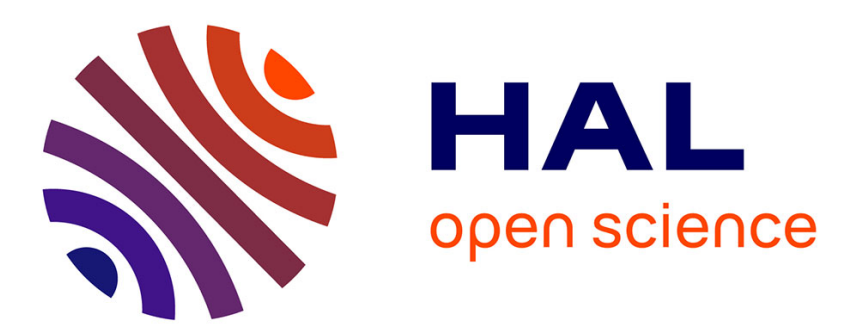

\title{
The Link Between Benevolence and Well-Being in the Context of Human-Resource Marketing
}

Catherine Viot, Laïla Benraiss-Noailles

\section{To cite this version:}

Catherine Viot, Laïla Benraiss-Noailles. The Link Between Benevolence and Well-Being in the Context of Human-Resource Marketing. Journal of Business Ethics, In press, 10.1007/s10551-018-3834-1 . hal-01803653

\section{HAL Id: hal-01803653 \\ https://hal.science/hal-01803653}

Submitted on 30 May 2018

HAL is a multi-disciplinary open access archive for the deposit and dissemination of scientific research documents, whether they are published or not. The documents may come from teaching and research institutions in France or abroad, or from public or private research centers.
L'archive ouverte pluridisciplinaire HAL, est destinée au dépôt et à la diffusion de documents scientifiques de niveau recherche, publiés ou non, émanant des établissements d'enseignement et de recherche français ou étrangers, des laboratoires publics ou privés. 


\title{
The link between benevolence and well-being in the context of human- resource marketing
}

\author{
Catherine Viot, Université Claude Bernard Lyon1, Laboratoire SAF \\ et Laïla Benraiss, IAE de Bordeaux, IRGO \\ À paraître dans Journal of Business Ethics (rang 2 CNRS)
}

DOI: $10.1007 / \mathrm{s} 10551-018-3834-1$

\begin{abstract}
Although interest in the subject of human-resource marketing is growing among researchers and practitioners, there have been remarkably few studies on the effects on employees of how benevolent their organization is. This article looks at the link between the presumption of organizational benevolence and the well-being of employees at work. The results of an empirical study of 595 employees show that the presumption of organizational benevolence is positively linked to employee well-being. The effect is indirect, as it is mediated by the perceived level of organizational support. The existence of a link between employee wellbeing and intention to quit the company is also confirmed.
\end{abstract}

\section{Keywords}

Human-resource marketing, presumption of organizational benevolence, well-being at work, perceived organizational support, intention to leave the job.

\section{List of abbreviations}

WB Well-being

POB Presumption of organizational benevolence

POS Perceived organizational support 
Well-being, which can be defined as "a pleasant state as a result of physical and spiritual satisfaction" (Dictionary Larousse), is, interestingly, a twofold concept: there is the social aspect (the well-being of people in general) and the individual aspect (the well-being of a particular person). Given the commonsense nature of this definition, it is not difficult to understand why well-being is of such interest in the world of marketing. By engaging in the act of consumption the individual can find a way to achieve or maintain a state of well-being. This feeling stems from having satisfied a need (Maslow, et al. 1970). Can it be considered, by analogy, that employee well-being constitutes a major stake in the context of humanresource management? A survey conducted in 2012 with 14,000 French employees found that the most important thing to them was "well-being at work", i.e. a good balance between work and home life, as well as a job that allows them to prosper. Salary was only the fifth most important thing. The survey also reveals that $32 \%$ of respondents intended to leave their employer (1).

It is now widely accepted that the term "consumption" covers a huge variety of situations. According to current thinking in human-resource marketing, the employee can be considered the client, the employer the brand, and the HR offering the product (Panczuk and Point, 2011). So, the notion of well-being is proving to be of great interest in the specific context of human-resource marketing, as employee well-being could drive employee loyalty and thus contribute to the overall performance of the company. Moreover, it involves both an individual element - the well-being of the employee as an individual - and a social element the well-being of the group of people that makes up the company or organization.

Another concept that is currently preoccupying company managers is benevolence, which is defined as "an inclination to understand and oblige others" (Larousse). In management theory, the concept of benevolence is as familiar in marketing as it is in human-resource marketing, and is considered in both contexts as a dimension of trust - in the brand (Gurviez and Korchia, 2002), first and foremost, but also in the employer (Rempel et al. 1985). Benevolence is therefore defined as "the willingness to assume that the other person will act honestly" (Brunel and Morrisson, 2008; p. 11). In marketing terms, this corresponds to having good intentions, prioritizing the client and paying attention to their needs (Ganesan, 1994, Doney and Cannon 1997). Researchers in the field of marketing are also interested in another concept linked to benevolence, which is the presumption of benevolence, defined by Frisou (2000) as the evaluation of the intentions attributed to the partner. This concept has not yet been transferred to the context of organizations, or of human-resource marketing. In fact, the presumption of benevolence on the part of a particular employee is based on a set of indicators and not on evidence.

It is not difficult to understand the managerial interest in exploring the relationship between the presumption of organizational benevolence and employee well-being and studying the effects of well-being on employee retention. Indeed, Generation Y, on the one hand, seems to have less long-term loyalty to employers than the previous generation and, on the other, values its personal well-being and has high expectations in terms of work-life balance. An empirical study was conducted among employees in order to test a number of hypotheses linking the concepts of well-being (WB), the presumption of organizational benevolence (POB) and perceived organizational support (POS).

To our knowledge, the link between employer benevolence and employee well-being has not yet been explored. Some research studied the influence of benevolence on trust between managers and subordinates (Lleó de Nalda et al. 2016; Poon, 2013). This research is one of the first to demonstrate the influence impact of employer benevolence on employee wellbeing. 
As for the influence of well-being on turnover, this research makes a distinction between positive and negative well-being, while in previous research well-being was measured by an average index making impossible to isolate the effect of positive and negative well-being on the intention to leave the company (Whright and Bonett, 2007).

This article is structured in four parts. The first concerns the concept of well-being as it is used in psychology, marketing and human-resource management, as well as one of its possible antecedents: benevolence. The second part focuses on the conceptual model and hypothesis. The results of the empirical study are presented in the third part. Then they are discussed.

\section{The concept of well-being in human-resource management}

Well-being is, first and foremost, a psychological state. Is such a state, as experienced by employees, of benefit for the organizations that employ them?

\section{Well-being as a psychological state}

Well-being is a positive psychological state that arises from how an individual perceives and assesses their life. "It is generally formulated around happiness and quality of life" (Gorge et al. 2015, p. 105). There are two conceptions of well-being: hedonic (or subjective) and eudaimonic (or psychological). In the first of these concepts, well-being is considered as a subjective assessment of life (Diener, 1984). For Ménard and Brunet (2012, p. 93), subjective well-being is "the sum or result of evaluative reactions to stimuli linked to existence that are encountered by the individual in various situations or walks of life, such as work, for example". There are two dimensions to subjective well-being: the search for reward (positive affects) and the avoidance of punishment (negative affects) (Massé et al. 1998).

In the eudaimonic concept, well-being is achieved when the individual succeeds in giving meaning to his/her life. So, it is measured in terms of the degree to which the individual perceives themselves as having achieved self-acceptance, control over their environment, positive relationships with others, life goals, personal growth, and autonomy (Ryff and Keyes, 1995). If well-being is generally held to be a positive psychological state, Warr (1990) sees it as a two-dimensional - positive and negative - construct.

Rolland (2000) notes that psychologists studying well-being have tended to focus on happiness. Bradburn (1969) considers it to be a state in which the positive affect, for a particular person, outweigh the negative. This is based on the author's assessment of subjective well-being by subtracting scores on the scale of negative emotions from those on the scale of positive emotions (positive emotions minus negative emotions). It is about two separate dimensions - positive and negative affects - whose independence has been evidenced by many research studies (Connolly and Viswesvaran 1999; Diener and Emmons 1985; Warr, et al. 1983; Watson and Clark, 1992).

Well-being at work - an affective construct different from job satisfaction, which is evaluative (Wright and Cropnazano, 1997), reflects the predominance of positive affects over negative ones (Diener and Larsen, 1993). In the field of human resources, several empirical studies have demonstrated the benefits of well-being. It helps improve performance and productivity (Wright and Cropanzano, 1997). It also helps reduce staff turnover (Wright and Bonett, 2007).

In previous literature, some antecedents of well-being were identified. In their study, Clarke and Mahadi (2017) found mutual recognition respect between leaders and followers predicted both follower job performance and well-being. Moreover, Ethical leadership is positively 
related to work engagement and emotional exhaustion - two indicators of employee wellbeing (Chughtai, Byrne and Flood, 2015).

\section{The presumption of benevolence as an antecedent of well-being}

The presumption of benevolence concept comes from marketing. Regarding the elements that constitute trust in a brand, of which benevolence is one, Frisou (2000) prefers to talk about presumption because, in his opinion, "the fact that a stimulus is perceived and involved does not necessarily mean it is accepted, or translated into trust" (Frisou, 2000, p. 68). The presumption of benevolence is therefore inherent in his concept of trust. It is a mental state, not directly observable, which is based more on indicators than evidence (Frisou, 2000). The presumption of benevolence "is a brand's ability to put the long-term interests of the consumer before its own short-term interests" (Gouteron, 2008, p. 116). The presumption of benevolence signifies the interest a brand has in its clients. Likewise, the presumption of benevolence of the employer brand (or presumption of organizational benevolence) signifies the interest an organization, as an employer, has in its staff.

\section{Conceptual model and hypotheses}

\section{Benevolence as an antecedent of well-being}

The way in which an organization manages human resources is an indicator of the attention it pays its employees. It has been shown that employee perception of their manager's behavioral integrity is positively related to job satisfaction, job engagement, health, and life satisfaction and negatively to stress, turnover likelihood, and work-to-family conflict (Prottas, 2013). Ethical leadership indirectly influences both employee well-being and life satisfaction, through job satisfaction (Yang, 2014). The way in which an organization manages human resources shows how much the employer values its employees and the degree to which it considers their well-being (Guerrero and Herrbach, 2009). Moreover, companies that offer practical employee benefits, such as flexible hours or on-site day care, would be seen by employees as considerate of their well-being (Bentein, 2000). When employees perceive the benevolence of their employer through fair treatment, this indicates the degree to which the organization values their contribution and cares about their well-being (Aselage and Eisenberger, 2003). Thus, the following hypothesis, H1, which links the presumption of organizational benevolence and well-being at work, can be stated:

Hypothesis 1 The presumption of organizational benevolence (POB) influences the wellbeing of employees at work. POB has a positive influence on the positive dimension of wellbeing (H1a), while POB has a negative influence on the negative dimension of well-being (H1b).

\section{The mediating role of perceived organizational support}

Perceived organizational support (POS) refers to employees' perception of their employer in terms of the degree to which the latter cares about them, values their efforts and personal commitment, and is interested in their professional well-being (Eisenberger et al. 1986). This belief depends on the sincerity and frequency of gestures of goodwill made by the employer towards employees, over and above contractual obligations (Aselage and Eisenberger, 2003).

The mediating role of POS has already been proved in previous literature. For example, Guerrero and Herrbach (2008) showed that the link between psychological contract fulfillment and affective states appears through POS and not directly. Similarly, we expect the POS to mediate the relationship between employer benevolence and employee well- 
being. This means that employee well-being (WB) is not a direct consequence of employer benevolence, but derives from the POS. We state that the perception about how an employer is benevolent is related to employer WB because it may generate a mindset, that is POS, which is both the outcome of employer benevolence and the antecedent of employee WB. POS thus captures the attitudinal component of employer benevolence, this is why it will fully mediate the relationship between employer benevolence and employee well-being.

If employees perceive that their company is fair, this is an indicator of the latter's benevolence. For Rhoades et al. (2001), procedural fairness plays a strong part in whether employees see an organization as benevolent or malevolent. For these authors, this perception - when it is positive - helps reinforce POS. Thus, hypothesis H2 can be stated:

Hypothesis 2 The presumption of organizational benevolence has a positive influence on POS.

For Rhoades et al. (2001), POS can help explain employees' emotional commitment to their organization. For these authors, employees, by developing general beliefs about the degree to which their employer takes their WB into account, determine how prepared the latter is to reward their efforts. Several studies have shown that POS is positively related to many positive outcomes (e.g., Baran et al., 2012; Kurtessis et al., 2015; Rhoades and Eisenberger, 2002). For Eisenberger and Stinglhamber (2011), the POS outcomes can be classified in three categories: favourable attitudes towards organization (e.g., affective commitment), beneficial behavioural outcomes (e.g., performance), and employee well-being. On the basis of these findings, hypothesis $\mathrm{H} 3$ can be postulated.

Hypothesis 3 POS influences well-being at work. POS has a positive influence on the positive dimension of well-being (H3a), while POS has a negative influence on the negative dimension of well-being (H3b).

\section{Internal effects of well-being at work}

While it has been shown that well-being is beneficial for employees, this present research is more concerned with its benefits for the organization. Nevertheless, it is worth recalling that those who experience a greater sense of well-being manage the various aspects of their lives better than others. They have more friendships, a higher level of self-confidence, progress further and are more engaged in their work, earn more money and enjoy better cardiovascular health (Diener et al. 2003).

For companies, employee well-being involves both external and internal factors. In their external efforts to differentiate themselves and be more attractive to potential employees, companies can promote the level of well-being they offer. The well-being of current employees constitutes real added value in the labor market (Creusier, 2013).

Internally, employee well-being has several benefits, including reduced staff turnover and absenteeism. In fact, staff turnover is often a major problem for companies. A survey of French workers in 2012 found that $32 \%$ of respondents intended to leave their employer (1). Even though it is acknowledged that retaining all employees could have a detrimental effect on skills renewal, staff turnover does become a major problem when it comes to skilled workers. Here, it represents a double loss for the company: a loss of skills and a financial loss. The latter can be quantified according to the cost of releasing the employee plus the costs of recruiting, inducting and training a replacement to get them up to speed. Staff turnover therefore has a negative impact on the company's performance. In the case of skilled 
employees, the cost has been estimated at 1.5 to 2.5 times the annual salary of the post-holder (Wright and Bonett, 2007). In France, staff turnover is likely to reach $15.1 \%$ by 2018 (2).

Back in 1931, Fisher and Hanna revealed the effects of well-being on employee withdrawal, on the likelihood of them being absent, and on their contribution to the company's financial performance (cited by Wright and Bonett, 2007, p. 144). Wright and Bonett (2007) held that employees with a low sense of well-being were much more likely to quit their job. Consequently, hypothesis H4 can be stated as follows:

Hypothesis 4 Well-being at work influences the intention to leave a company. The positive dimension of well-being has a negative influence on the intention to leave a company (H4a), while the negative dimension of well-being has a positive influence on the intention to leave a company (H4b).

Hypotheses $\mathrm{H} 1$ to $\mathrm{H} 4$ emphasize the relationships between the concepts of presumption of organizational benevolence, POS, well-being, and their direct or indirect effects on the intention to leave a company (Fig. 1).

INSERT FIGURE 1 ABOUT HERE

\section{Empirical study and results}

An empirical study was carried out in Spring 2016 to test this research model.

\section{Sample}

The questionnaire was sent by e-mail to employees of companies in the "Nouvelle-Aquitaine" region of France. These companies are referenced in databases made available by the Chamber of Commerce.

The data were collected in two batches. An initial sample of 110 individuals provided the basis for exploratory analyses, followed by a second round, in which 842 questionnaires were collected. The questionnaires were distributed to 7794 employees. After eliminating temporary employees, trainees, job-seekers and business owners, there were 95 viable questionnaires from the first collection and 500 from the second.

The characteristics of the two samples were very similar (table 1).

INSERT TABLE 1 ABOUT HERE

In the second sample, the study covers a very large number of industries, the most common of which were personal services $(28.4 \%)$, business services $(26.4 \%)$ and manufacturing \& construction $(22.4 \%)$.

\section{Measurement of concepts}

The concepts involved had been measured according to approved scales. Some were used as already established, such as POS and intention to leave the company. Others had to be 
adapted, such as well-being and the presumption of benevolence. The items associated with each of the scales are shown in table 2.

Warr's scale (1990), which comprises 12 items, was used to measure employee well-being. It was designed to measure well-being both at work and outside of it, depending on the wording of the question. In the work-related version, the respondent is required to assess, according to a six-point scale ranging from 'never' to 'always', how often they have experienced certain feelings over the previous two weeks.

The scale comprises 12 feelings - six positive (calm, contented, relaxed, cheerful, enthusiastic, optimistic) and six negative (tense, uneasy, worried, depressed, gloomy, miserable).

The scale measuring the brand's presumption of benevolence (Frisou, 2000) was adapted to the company as employer to measure the presumption of benevolence of the employer. It comprises four items.

Examples of items are "the company takes you seriously" and "the company takes care of your interests".

POS was measured using the Coyle-Shapiro and Conway scale (2005). They selected the seven items with the highest factorial contributions to Eisenberger et al's original scale (2001), which comprises 36 items.

Examples of items are "My employer values my contributions to its well-being"; "My employer cares about my opinions".

One way of dealing with employee retention is to question them on whether or not they intend to leave the company where they are employed. The intention to quit, considered to be the best indicator for the adoption of obvious withdrawal behavior (Giraud, 2015), reflects an employee's desire to leave the company voluntarily (Moore, 2000). Moore's unidimensional scale (2000), comprising 4 items, was used to measure the intention to quit the company.

Examples of items are "I will probably look for a job at a different company in the next year"; "I will take steps during the next year to secure a job at a different company".

\section{Exploratory analyses}

In the first instance, the validity of these scales was determined based on a sample of 95 individuals and with the help of exploratory factorial analyses (principal component analyses). The hypotheses were then tested on a second sample of 500 individuals, using structural equation modeling. The principal component analyses (PCAs) showed that of the scales selected for the empirical study, three required no adaptation, i.e. intention to quit, the presumption of benevolence and POS.

The presumption of benevolence scale proved to be bi-dimensional (one positive, one negative factor). Three items, for which either the scores were below 0.5 , or the correlation with the two factors was relatively high, were discarded. These three items were 'calm', 'relaxed' and 'tense' (table 2).

INSERT TABLE 2 ABOUT HERE 


\section{Confirmatory analyses}

\section{Measurement model}

Although these scales had already been subjected to confirmatory analyses in previous papers (Guerrero and Herrbach 2009; Holman et al. 2002), confirmatory factorial analyses (CFA) were carried out in order to test measurement models (table 3). Systematic bootstrapping was applied to determine a confidence interval and the statistical significance of each estimated parameter.

\section{INSERT TABLE 3 ABOUT HERE}

The reliability of the scales was determined with the help of Jöreskog's rho (1971). It varied from 0.83 to 0.94 , thereby demonstrating good reliability. The convergent validity was established using the average variance extracted (AVE) (Fornell and Larcker, 1981). This must be higher than or equal to 0.5. When the AVE is above 0.5, the variance of a construct is better explained by the items which measure it than by error. This condition is satisfied in the case of all unidimensional scales and for the two dimensions of well-being. In the case of the bi-dimensional measurement scale for well-being, the discriminant validity of the different factors must also be established. Discriminant validity is confirmed if the AVE of a dimension is superior to the square of every correlation between itself and other latent concepts (Anderson and Gerbing, 1988). This condition is also satisfied: in fact, the square of the correlation between the positive and negative dimensions of well-being is 0.41 , while the AVE of the two dimensions of well-being was 0.64 and 0.5. Therefore, the measurement scales used in this research satisfy the conditions of reliability, convergent validity and discriminant validity (for well-being). Moreover, all loadings are statistically significant at $\mathrm{p}<0.01$. The goodness-of-fit statistics are also acceptable (SRMR $<0.08$; RMSEA $<0.07$, except for the Intention to quit scale; GFI and AGFI $>0.9$; significant $\chi^{2}$ except for the scale of presumption of benevolence).

\section{Explanatory model}

Structural equation modeling (with AMOS) was used to test the hypotheses of the causal model. The parameters of the model were estimated with the maximum likelihood method. A bootstrap was applied to determine a confidence interval and the statistical significance of the estimated parameters (table 4 and Fig. 2).

INSERT FIGURE 2 ABOUT HERE

Goodness-of-fit indices are within the optimum norms defined by Hair et al. (2014, table 4, p. 584): $\chi^{2}=624.19$ for 245 dof $(\mathrm{p}<0.001)$. GFI is 0.906; SRMR, 0.093; RMSEA, 0.056; and TLI, 0.955 . 
The results show that hypotheses $\mathrm{H} 1$ to $\mathrm{H} 4$ are confirmed. The presumption of organizational benevolence is positively linked to employee well-being (H1) and POS (H2). POS has a positive influence on well-being at work $(\mathrm{H} 3)$. Hypothesis $\mathrm{H} 4$ is also confirmed: The positive dimension of well-being at work has a negative influence on the intention to leave a company (H4a), while the negative dimension of well-being at work has a positive influence on the intention to leave a company $(\mathrm{H} 4 \mathrm{~b})$.

However, it must be tested whether POS is really a mediating variable in the relationship between POB and well-being at work. The method recommended by Baron and Kenny (1981), which consists of a series of regressions, was applied, using SPSS. The stages are detailed below.

1) The predictor variable (POB) predicts the dependent variable (positive and negative wellbeing). The relationship between $\mathrm{POB}$ and positive well-being is positive $\left(0.605^{* * *}\right)$, while the relationship between POB and negative well-being is negative (-0.594**).

2) The predictor variable (POB) is a positive predictor of the mediating variable (POS) $(.864 * * *)$.

3) The mediating variable (POS) is a significant predictor of the two dimensions of the dependent variable (positive and negative well-being) when both the predictor variable (POB) and the mediating variable (POS) are included in a multiple regression analysis. The relationship between POS and positive well-being is positive $\left(0.469^{* * *}\right)$, while the relationship between POS and negative well-being is negative $\left(-0.400^{* * *}\right)$.

The role of POS as a mediator differs depending on whether the relationship being considered is between POB and positive well-being or negative well-being. When it is positive, the mediation of SOP is full, but when it is negative, the mediation of SOP is partial (Fig. 3).

INSERT FIGURE 3 ABOUT HERE

4) The indirect effects are then calculated and their statistical significance determined using the Sobel's test (Sobel, 1982). This involves calculating an estimation of the standard deviation of the product of coefficients. The latter is assumed to follow a normal distribution. The Quantpsy.org simulator was used for this test. The indirect effects were statistically significant in both cases (positive well-being: $Z=6.797 ; p<0.001$ ) and negative well-being: $Z$ $=-5.145 ; \mathrm{p}<0.001)$.

In the context of human-resource marketing, therefore, the effect of the presumption of organizational benevolence on well-being should be considered to have an indirect effect via POS. In terms of the effect of the presumption of organizational benevolence on positive well-being, this mediation is full. In the case of the presumption of organizational benevolence on negative well-being, this mediation is partial. 


\section{General discussion}

\section{Theoretical perspectives}

This research updates, from a theoretical point of view, the findings from several previous studies. First, it shows that the presumption of benevolence - a concept from marketing used in relation to brand (Frisou, 2000) - can be applied to human-resource marketing in the form of a presumption of organizational benevolence. This concept can be defined as the ability of the organization to sustainably consider the interests of its employees in the short term. This presumption of employer benevolence is a form of organizational altruism that is not directly observable, because it is based on indicators more than evidence.

Second, this research has identified two antecedents of well-being at work. Essentially, two variables influence employee well-being: the presumption of benevolence of the employer and POS. An employer who listens to their employees and cares about their interests is presumed benevolent. This presumption of benevolence is positively and directly linked to the positive well-being of employees and negatively and directly linked to their negative well-being. If the employer formalizes this benevolence towards their employees by implementing supportive Human Resource Marketing practices (flexible working hours, learning opportunities, on-site day care, etc.), its effect on employees' well-being at work is stronger.

Finally, this research enabled empirical testing of the impact of well-being at work on the intention to quit the company. The results show that employees who experience positive/negative well-being have a weak/strong intention to leave their employer. It is therefore confirmed that well-being at work has an effect on employee retention.

\section{Managerial implications}

\section{Benevolence, POS and well-being}

Organizational benevolence promotes employee well-being and POS. How can the employer demonstrate benevolence towards employees in order to improve well-being and POS? To try to answer this question, the theory of former President of the French Institute for Strategic Analysis (IFAS), Eric Albert, that there are four levels of benevolence, will be used as a guide (4). In 2012, he declared that "the benevolent company does not exist. [Benevolence is an] ideal that can never be fully achieved [which] can act as a guideline to inspire and inform how we all go about our daily lives. It's what we commonly refer to as a value." $\mathrm{He}$ identified four levels of benevolence, with which actions can be associated.

The first level is working conditions, which includes everything that can be done within a company to make the lives of employees easier (from building maintenance to massage therapy sessions).

The second level of benevolence covers company rules to avoid abuse of staff time and availability (meeting times, use of email, particularly outside of working hours, etc.). The company KPMG is an example of good practice. It has developed two benevolence charters. The first, called No Stress, identifies 10 managerial behaviors to combat stress, including courtesy and respect (even under pressure), recognizing success, clear understanding of the job, feedback, etc. The second charter, VP2, focuses on the relationship between home and work life: no meetings to start after $6.30 \mathrm{pm}$, support for new mothers on their return to work after maternity leave, no emails to be sent over the weekend, etc. Such Human Resource Marketing practices - or the Human Resource marketing offering - are designed to reinforce 
the image of the benevolent and supportive employer in the minds of the employees, thus improving their well-being and weakening their intention to quit. They also help attract the best candidates looking for a job by allowing them to reconcile their home and work lives.

The list of good practices goes on. For example, there are "The 10 commandments of benevolence": be polite, have empathy, be available, be punctual, smile, be trustworthy, be positive, be optimistic, keep calm, and spread the good word on benevolence. The Lachmann et al. (2010) report, compiled by Human Resource practitioners for the French prime minister in 2010, contains 10 proposals for improving psychological well-being at work (5), including: train managers how to be managers, involve the company leadership, measure - because what gets measured gets done, etc.

The third level is about the quality of the relationships between the parties involved. Benevolence is about changing managerial habits and moving away from the prescriptive management style of giving orders and expecting them to be obeyed. It is about demonstrating politeness and kindness towards employees, listening to them and encouraging them to make suggestions, being respectful towards them, praising them for a job well done. These new habits make up a set of indicators that favor a presumption of organizational benevolence among employees. Simply announcing that change needs to happen is not enough. Local managers need to be trained in benevolent management. Relevant courses are available and can help local managers develop better relationships with operational staff (6). In a distribution company, for example, the store boss helps with unloading and stacking, and is polite and kind to the workers, even when they have to reprimand them. In a chocolate factory, the workers can choose their hours, their co-workers and the machines that are installed. They can change department on request to avoid repetitive work. Ideas are encouraged and often implemented. Since adopting a system of benevolent management, the company's turnover has increased by $25 \%$ (in three years).

The fourth and final level concerns governance and the distribution of profits among the various stakeholders. Sound and transparent governance can be considered a clear indicator of organizational benevolence. A benevolent organization has at heart the interests of all its stakeholders and the impact it may have on them. There are many ways for companies to ensure employees - one of their stakeholder groups - can share in profits (incentives, profitsharing, savings plans, share ownership). They could expand this in a socially responsible way, by taking into account the situation and needs of communities affected by their activities.

Cohen (2013) examines the positive effects of profit sharing. According to this author, sharing, for employees, strengthens motivation and reduces absenteeism, improves productivity, facilitates access to housing and, finally, offers them a simple and attractive way to improve the prospects for their retirement. More globally, sharing impacts favorably on employment - especially in SMEs - and improves a company's value (those that have a high level of employee share ownership are valued higher than others).

Well-being at work and the intention to leave

A 2014 study published by DIRECCTE (7) on well-being and economic performance highlighted the effect of well-being at work on reducing absenteeism, staff turnover, workplace accidents, production delays, quality defects, pyscho-social risks etc. In this regard, the experience of Teem Photonics, a leading SME in the lasers industry, based in Isère (France), is telling. The Human Resource department did substantive work with Human Resource personnel to analyze the root causes of the gloomy atmosphere in the SME. As a result, they discovered a desire for more information on the day-to-day operation of the company, its development and its sales performance. The company subsequently took action to improve internal communication. It also focused on hospitality, organizing free coffee and 
croissants every Friday, which helped in terms of better sharing of information. In addition, the HR department set up a dynamic training program, with personal development plans and information sessions on training entitlements. Finally, it worked to resolve certain conflicts by undergoing training in mediation. All of this helped reduce absenteeism from $8 \%$ to $2 \%$ and staff turnover is now practically zero at the company.

Benevolence also involves a company's hierarchy. A company is considered benevolent when its managers share this conviction and put it into practice every day. In fact, benevolence is maintained and preserved through regular practice. Having a good relationship with the management is essential, in this respect.

\section{Avenues of research}

The results observed in this empirical study highlight the link between employee well-being and company performance. Further research should be conducted, therefore, to identify other factors that contribute to employee well-being. Benevolence, while certainly an important antecedent of well-being, is by no means the only one. Indeed, studies of well-being demonstrate the various dimensions it can encompass.

Do all employees have the same expectations, or do some of them value material well-being (higher salary, job security), physical well-being (health, no stress), and psychological wellbeing (good work/life balance) more highly? This study was conducted in France, so would the results be similar in another country? One avenue of research is to test this model in another cultural context. Another avenue could be to identify the impact of organizational benevolence on the attractiveness of the company as an employer. This future research could be based on experiments, i.e. creating scenarios in which the degree of benevolence and means of communication can be manipulated, in order to test how the effects on attractiveness affect potential employees.

We identified, in the managerial implications, the potential impact of employee well-being on withdrawal behavior, such as absenteeism and lateness. In further research, we suggest to test the effect of benevolence on work-related stress, and to identify managers' benevolent behaviors. This benevolent management could allow reducing the pressure put on employees without affecting their productivity and performance.

There are two other avenues of research which do not fall strictly within the field of humanresource marketing. First, can the relationship between organizational benevolence and wellbeing at work be extended? In other words, to what extent does the effect of employee wellbeing affect consumer responses (satisfaction, loyalty, etc.)?

And then, is this relationship transferable to the context of goods and services marketing? In other words, is a benevolent brand a source of well-being for the consumer? Are there variables which, like POS, would play the role of mediator between the benevolence of the brand and the well-being of the consumer? Can a brand that cares about the well-being of its clients expect greater loyalty from them?

\section{Conclusion}

To the best of current knowledge, no empirical study has proposed explicitly to link the presumption of benevolence and POS to well-being at work. Nevertheless, there is a strong managerial interest in such a link because it underpins a double process of reciprocity. Those who perceive their organization as benevolent and feel supported by it experience, in turn, a greater sense of well-being at work and a reduced desire to leave their employer. This research has enabled empirical confirmation of this relationship, in the large number of industries, and thus fills this gap in the literature. 


\section{Notes}

(1) Kelly service survey

http://www.kellyservices.fr/uploadedFiles/Dev_Kelly_Services(1)/rapport

$\% 20 \mathrm{KGWI} \% 20 \mathrm{n} \% \mathrm{C} 2 \% \mathrm{~B} 01 . \mathrm{pdf}$

(2) According to a study by Hay Group, in partnership with CEBR (Center for Economics and Business Research), the rate of employee turnover in France in 2013 was 13.7\%. The study found that $30 \%$ of employees wanted to stay with their current company for between 3 and 5 years - the second highest rate in Europe. Furthermore, the study showed that, by 2018, the turnover rate would increase by two percentage points (to 15.1\%), http://www.myrhline.com/actualite-rh

(3) Hair et al. (2014) consider that chi-2 should be considered less essential than other adequacy indicators that are often used at present (p. 582). They pointed out that a small number of observed variables (less than 12) is commonly translated as a non-significant chi-2 (table 4, p. 584).

(4) https://business.lesechos.fr/directions-ressources-humaines/ressources-humaines/bienetre-au-travail/ 0202401131362-la-bienveillance-a-t-elle-sa-place-au-travail-2901.php

(5) Les Echos Le Cercle: https://www.lesechos.fr/idees-debats/cercle/cercle-164869-les-10commandements-de-la-bienveillance-en-entreprise-2056939.php

(6) Les Echos Le Cercle: https://www.lesechos.fr/idees-debats/cercle/cercle-164869-les-10commandements-de-la-bienveillance-en-entreprise-2056939.php

(7) French Directorates for Enterprise, Competition Policy, Consumer Affairs, Labor and Employment: http://www.santeperformance.fr/documents/ressources/bien-etre-au-travail-etperf-eco-direcctera.pdf

\section{Compliance with ethical standards:}

Author identifying information - on the title page that is separate from the manuscript:

Conflict of interest: Author A declares that he/she has no conflict of interest. Author B declares that he/she has no conflict of interest.

Ethical approval: All procedures performed in studies involving human participants were in accordance with the ethical standards of the institutional and/or national research committee and with the 1964 Helsinki declaration and its later amendments or comparable ethical standards.

Ethical approval: This article does not contain any studies with animals performed by any of the authors.

Informed consent: Informed consent was obtained from all individual participants included in the study.

\section{References}

Allen, N. J., \& Meyer, J. P. (1990). The measurement and antecedents of affective, continuance and normative commitment to the organization. Journal of Occupational Psychology, 63(1), 1-18.

Anderson, J. C., \& Gerbing, D. W. (1988). Structural Modeling in practice: a review and recommended two steps approach. Psychological Bulletin, 103(3), 411-423.

Aselage, J., \& Eisenberger, R. (2003). Perceived organizational support and psychological contracts: a theoretical integration. Journal of Organizational Behavior, 24(5), 491-509.

Baran, B., Rhoades, L., \& Miller, L. (2012). Advancing organizational support theory into the twenty-first century world of work. Journal of Business and Psychology, 27(2), 123-147.

Baron, R. M., \& Kenny, D. A. (1986). The moderator-mediator variable distinction in socialpsychological research: conceptual, strategic, and statistical considerations. Journal of 
Personality and Social Psychology, 51(6), 1173-1182.

Bradburn, N. M. (1969). The structure of psychological well-being. Chicago: Aldine.

Brunel, O., \& Morrisson, O. (2008). Les effets médiateurs de la confiance et de l'attachement dans la relation satisfaction-intentions de réachat pour le traitement des réclamations. XXIV ${ }^{\text {th }}$ Annual Conference of the AFM (Association Française de Marketing), Paris, 15-16 May 2008.

Chughtai, A., Byrne, M., \& Flood, B. (2015). Linking Ethical Leadership to Employee WellBeing: The Role of Trust in Supervisor, Journal of Business Ethics, 128(3), 653-663.

Clarke, N., \& Mahadi, N. (2017). Mutual Recognition Respect Between Leaders and Followers: Its Relationship to Follower Job Performance and Well-Being, Journal of Business Ethics, 141(1), 163-178.

Cohen, R. H. (2013). Plaidoyer pour un leadership bienveillant. L'Expansion Management Review, 1(148), 90-99.

Connolly, J. J., \& Viswesvaran, C. (1999). Positive and negative Affect: A meta-analysis. Presentation at the 14th Annual Conference of the Society for Industrial and Organizational Psychology, Atlanta, GA; April 1999.

Coyle-Shapiro, J., \& Conway, N. (2005). Exchange relationships: examining psychological contracts and Perceived Organizational Support. Journal of Applied Psychology, 90(4), 774781.

Diener, E. (1984). Subjective well-being. Psychological Bulletin, 95(3), 542-575.

Diener, E., \& Emmons, R. A. (1985). The independence of positive and Negative Affect. Journal of Personality and Social Psychology, 47(5), 1105-1117.

Diener, E., \& Larsen, R. J. (1993). The experience of emotional well-being. In M. Lewis and J.M. Havilland (Eds), Handbook of emotions. New York: Guildford Press.

Diener, E., Oishi, S., \& Lucas, R. E. (2003). Personality, culture, and subjective well-being: Emotional and cognitive evaluations of life. Annual Review of Psychology, 54(1), 403-425.

DIRECCTE (2014). Bien-être au travail \& performance économique. Le sens et la reconnaissance au cœur de la performance. June, 8-17. http://www.rhonealpes.direccte.gouv.fr/

Eisenberger, R., \& Stinglhamber, F. (2011). Perceived organizational support: Fostering enthusiastic and productive employees. Washington, DC: APA Books.

Eisenberger, R., Armeli, S., Rexwinkel, B., Lynch, P. D., \& Rhoades, L. (2001). Reciprocation of Perceived Organisational Support. Journal of Applied Psychology, 86(1), 42-51.

Eisenberger, R., Huntington, R., Hutchison, S., \& Sowa, D. (1986). Perceived Organizational Support. Journal of Applied Psychology, 71(3), 500-507.

Fornell, C., \& Larcker, D.F. (1981). Evaluating structural equation models with unobservable variables and measurement error, Journal of Marketing Research, 18(1), 39-50.

Frisou, J. (2000). Confiance interpersonnelle et engagement : une réorientation béhavioriste. Recherche et Application en Marketing, 15(1), 63-80.

Giraud, L. (2015). L'intention de quitter l'entreprise : une approche par l'étape de carrière. Revue de Gestion des Ressources Humaines, 3(97), 58-86.

Gorge, H., Özçaglar-Toulouse, N., \& Toussaint, S., (2015). Bien-être and well-being in consumer research: A comparative analysis. Recherche et Applications en Marketing (English Edition), 30(2), 104-123.

Gouteron, J. (2008). L'impact de la personnalité de la marque sur la relation à la marque dans 
le domaine de la téléphonie mobile. La Revue des Sciences de Gestion, 5(233), 115-127.

Guerrero, S., \& Herrbach, O. (2008). The affective underpinnings of psychological contract fulfilment. Journal of Managerial Psychology, 23(1), 4-17.

Gurviez, P., \& Korchia, M. (2002). Proposition d'une échelle de mesure multidimensionnelle de la confiance dans la marque. Recherche et Applications en Marketing, 17(3), 41-61.

Hair, J. F. Jr, Black, W. C., Babin, B. J., \& Anderson, R. E. (2014). Multivariate data analysis, 7th Edition, Pearson New International Edition, 734 pages.

Holman, D., Chissick, C., \& Totterdell, P. (2002). The effects of performance monitoring on emotional labor and well-being in call centers. Motivation and Emotion, 26(1), 57-81.

Kurtessis, J., Eisenberger, R., Ford, M. T., Buffardi, L. C., Stewart, K. A., \& Adis, C. S. (2015). Perceived organizational support: A meta-analytic evaluation of organizational support theory. Journal of Management. Advance online publication.

Lachmann, H., Larose, C., Penicaud, M., \& Moleux, M. (2010). Bien-être et efficacité au travail, Dix propositions pour améliorer la santé psychologique au travail. Rapport au Premier ministre, La Documentation française, April 2010.

Lleó de Nalda, A., Guillén, M., \& Gil Pechuán, I. (2016). The influence of ability, benevolence, and integrity in trust between managers and subordinates: the role of ethical reasoning. Business Ethics: A European Review, 25(4) 556-576.

Maslow, A. H., Frager, R., \& Cox, R. (1970). Motivation and personality, Vol.2, in J. Fadimand et C. McReynolds (Eds.), Motivation and personality. New York: Harper \& Row.

Massé, R., Poulin, C., Dassa, C., Lambert, J., Bélair, S., \& Battaglini, A. (1998). Élaboration et validation d'un outil de mesure du bien-être psychologique: L'ÉMMBEP. Revue Canadienne de Santé Publique, 89(5), 352-357.

Ménard, J., \& Brunet, L. (2012). Authenticité et bien-être au travail : une invitation à mieux comprendre les rapports entre le soi et son environnement de travail. Pratiques Psychologiques, 18(1), 89-101.

Moore, J. E. (2000). One road to turnover: An examination of work exhaustion in technology professionals. MIS Quarterly, 24(1), 141-168.

Panczuk, S., \& Point, S. (2011). Enjeux et outils du marketing EH. Promouvoir et vendre les ressources humaines. Editions Eyrolles.

Poon, J. M. L. (2013). Effects of benevolence, integrity, and ability on trust-in-supervisor, Employee Relations, 35(4), 396-407.

Prottas, D. J. (2013). Relationships Among Employee Perception of Their Manager's Behavioral Integrity, Moral Distress, and Employee Attitudes and Well-Being, Journal of Business Ethics, 113(1), 51-60.

Rempel, J. K., Homes, J. G., \& Zanna, M. P. (1985). Trust in close relationships, Journal of Personality and Social Psychology, 49(1), 95-112.

Rhoades, L., \& Eisenberger, R. (2002). Perceived organizational support: A review of the literature. Journal of Applied Psychology, 87, 698-714.

Rhoades, L., Eisenberger, R., \& Armeli, S. (2001). Affective commitment of the organization: the contribution of Perceived Organizational Support, Journal of Applied Psychology. 86(5), 825-836.

Rolland, J.-P. (2000). Le bien-être subjectif : Revue de question. Pratiques Psychologiques, $1,5-21$.

Ryff, S. D., \& Keyes, C. L. M. (1995). The structure of psychological well-being revisited. Journal of Personality and Social Psychology. 69(4), 719-727. 
Shore, L. M., \& Wayne, S. J. (1993). Commitment and employee behaviour: Comparison of affective commitment and continuance commitment with perceived organization support. Journal of Applied Psychology, 78(5), 774-780.

Sobel, M. E. (1982). Asymptotic intervals for indirect effects in structural equation models, in S. Leinhart (Ed.), Sociological Methodology 1892, (pp. 290-312). San Francisco: JosseyBass.

Stanfeld, S. A., Fuhrer, R., Shipley, M. J., \& Marmot, M. G. (1999). Work characteristics predict psychiatric disorders: prospective results from Whitehall II Study. Occupational and Environmental Medicine, 56(2), 302-307.

Warr, P. (1990). The measurement of well-being and other aspects of mental health. Journal of Occupational Psychology, 63(3), 193-210.

Warr, P., Barter, J., \& Brownbridge, G. (1983). On the independence of positive and negative affect. Journal of Personality and Social Psychology, 44(3), 644-651.

Watson, D., \& Clark, L.A. (1992). On traits and temperament: general and specific factors of emotional experience and their relation to the Five Factor Model. Journal of Personality, 60(2), 441-476.

Wright, T. A., \& Bonett, D. G., (2007). Job satisfaction and psychological well-being as nonadditive predictors of workplace turnover. Journal of Management, 33(2), 141-160.

Wright, T. A., \& Cropanzano, R. (1997). Well-being, satisfaction and job performance: Another look at the happy/productive worker thesis. Academy of Management Proceedings. Academy of Management. 364-368.

Yang, C. (2014). Does Ethical Leadership Lead to Happy Workers? A Study on the Impact of Ethical Leadership, Subjective Well-Being, and Life Happiness in the Chinese Culture, Journal of Business Ethics, 123(3), 513-525. 


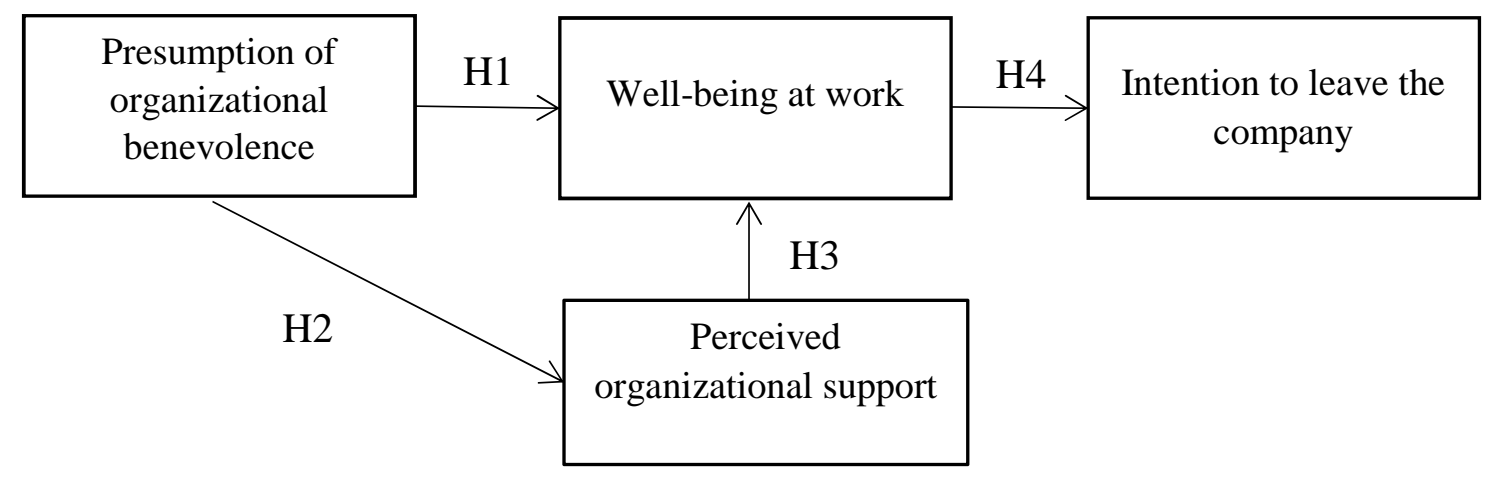

Fig.1 Research Model 


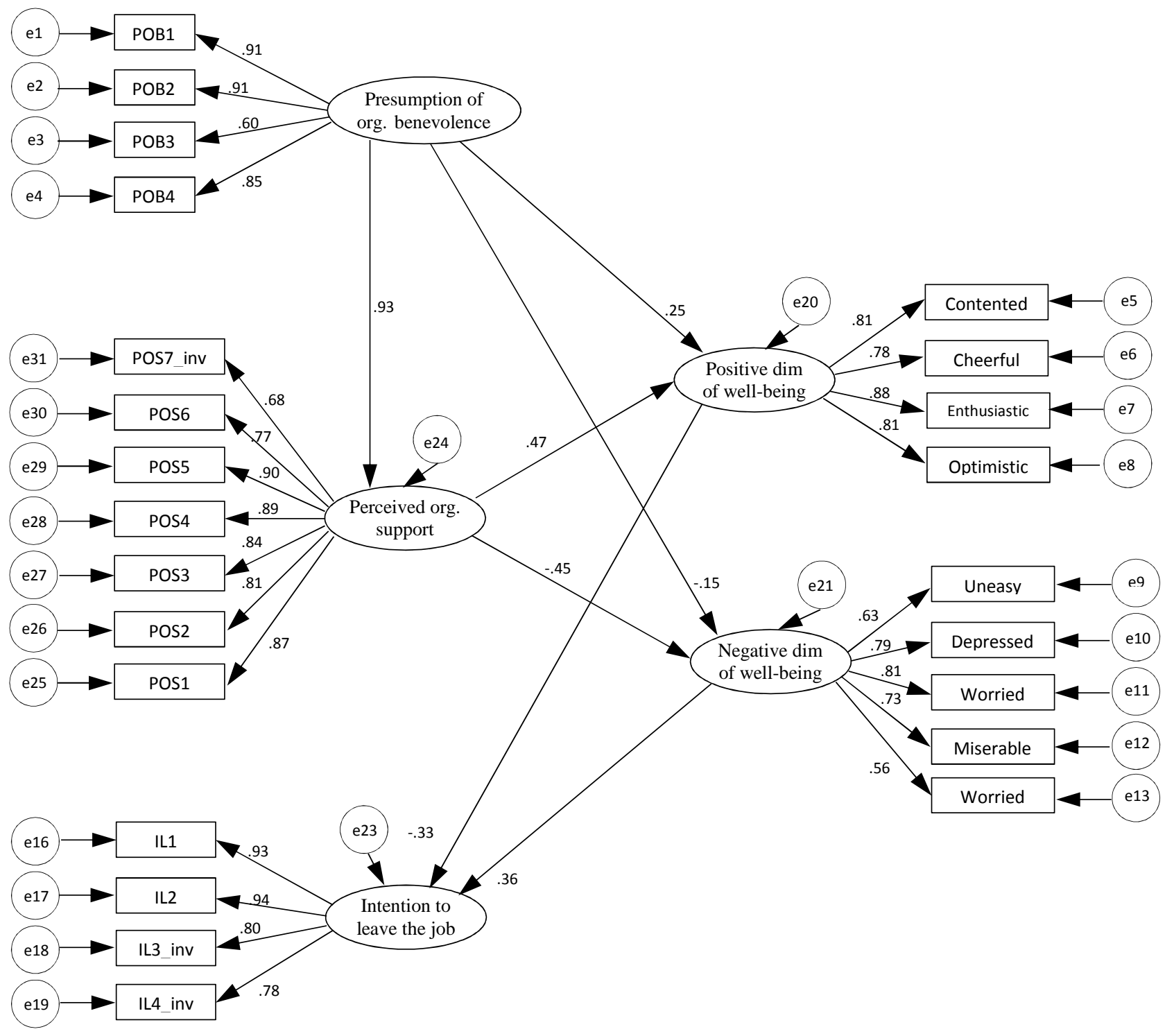

Fig.2 Structural modeling analysis results

AMOS (the structural equation modeling module of IBM SPSS software) was used to test the causal model and hypotheses. 

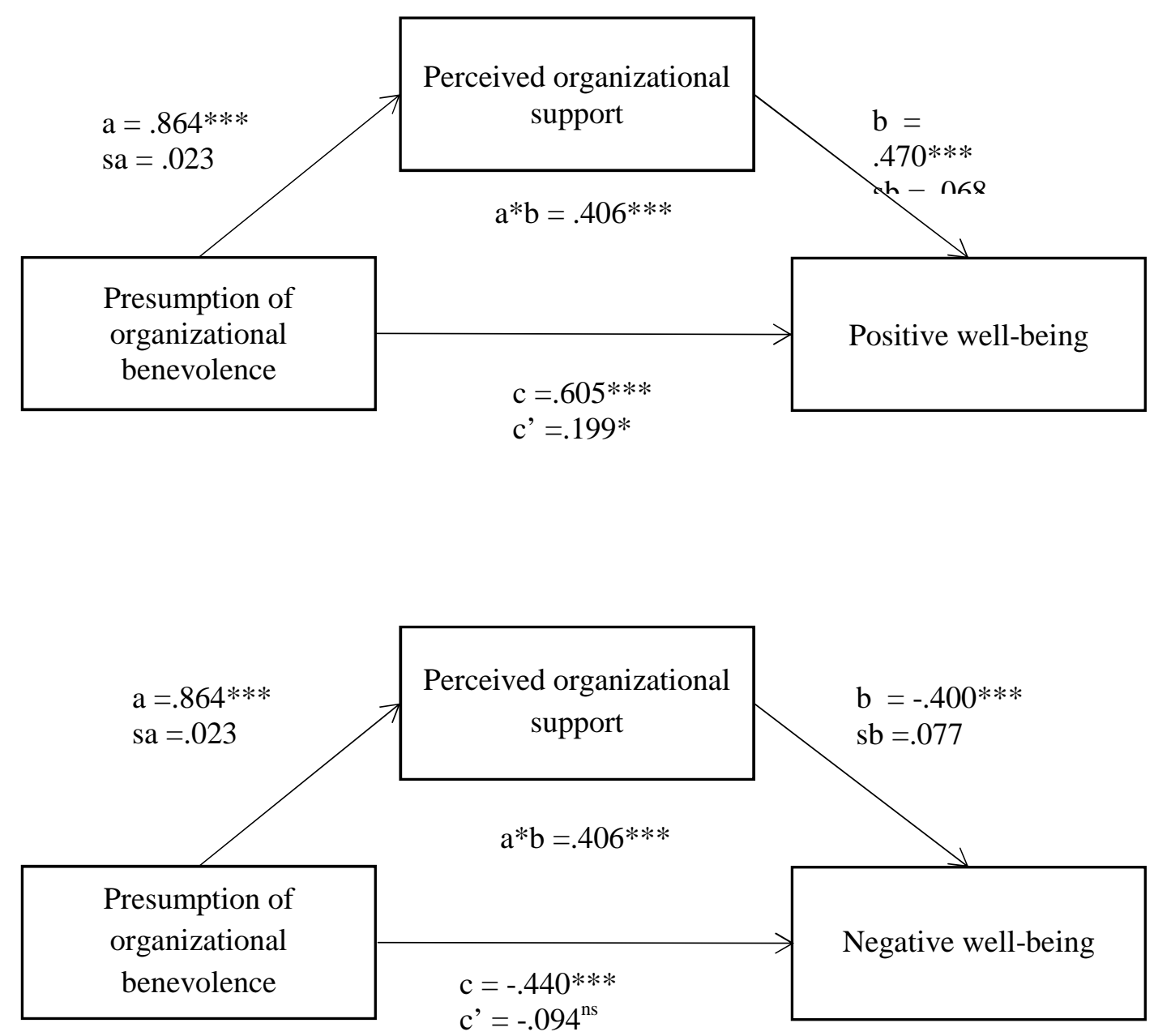

$a, b, c=$ Unstandardized coefficients

$s a=$ Standard error of $a$

$s b=$ Standard error of $b$

$c^{\prime}=$ Partial coefficient (multiple regression)

$a^{*} b=$ Indirect effect

Fig.3 The mediating effect of perceived organizational support

The mediating effect of POS was tested by respecting the procedure recommended by Baron and Kenny (1981) and completed by the Sobel's test (Sobel, 1982). 
Table 1 Characteristics of samples

\begin{tabular}{llll}
\hline \multicolumn{2}{c}{ Respondents characteristics } & $\begin{array}{l}\text { Sample 1 } \\
\text { (percent) }\end{array}$ & $\begin{array}{l}\text { Sample 2 } \\
\text { (percent) }\end{array}$ \\
\hline \multirow{2}{*}{ Gender distribution } & Men & 57 & 58 \\
& Women & 43 & 42 \\
\hline Distribution by business & Private sector employees & $87 *$ & $85.5 * *$ \\
sector: private / public & Public sector employees & 13 & 14.5 \\
\hline \multirow{5}{*}{ Distribution by age } & Under 25 years & 4.8 & 5 \\
& 25-35 years & 24 & 25 \\
& 36-45 years & 27.3 & 26.8 \\
& 46-55 years & 35 & 34.6 \\
\hline \multirow{3}{*}{ Distribution by level of } & More than 55 years & 8.9 & 8 \\
diploma & No diploma & 2.5 & 2 \\
& Bachelor's degree & 24.7 & 20.8 \\
& Master's degree & 54 & 57.2 \\
\hline
\end{tabular}

Note:

* $90 \%$ of the employees of the private sector have a permanent employment contract.

** $91 \%$ of the employees of the private sector have a permanent employment contract. 
Table 2 Synthesis of Principal Component Analyses

\begin{tabular}{|c|c|c|c|}
\hline \multicolumn{4}{|c|}{$\begin{array}{c}\text { Presumption of organizational benevolence } \\
\text { KMO }=0.840 ; \text { Bartlett: } \chi^{2}=277 ; \text { dof }=6 ; \mathrm{p}<0.001 \\
\text { Variance explained }=79.18 \%\end{array}$} \\
\hline $\begin{array}{l}\text { Cronbach's } \\
\text { alpha }\end{array}$ & Item & Loading & Communality \\
\hline \multirow{4}{*}{$\begin{array}{l}\text { One- } \\
\text { dimensional } \\
\alpha=0.912\end{array}$} & $\begin{array}{l}\text { POB } 1 \text { - The company is sincerely for your } \\
\text { listening. }\end{array}$ & .911 & .831 \\
\hline & $\begin{array}{l}\text { POB2 - The company takes care of your } \\
\text { interests. }\end{array}$ & .917 & .840 \\
\hline & $\begin{array}{l}\text { POB } 3 \text { - The company considers you as a } \\
\text { friend. }\end{array}$ & .792 & .628 \\
\hline & POB4 - The company is always kind to you. & .932 & .869 \\
\hline \multicolumn{4}{|c|}{$\begin{array}{c}\text { Perceived organizational support (POS) } \\
\mathrm{KMO}=0.909 ; \text { Bartlett: } \chi^{2}=565.38 ; \text { dof }=21 ; \mathrm{p}<0.001 \\
\text { Variance explained }=72.74 \%\end{array}$} \\
\hline $\begin{array}{l}\text { Cronbach's } \\
\text { alpha }\end{array}$ & Item & Loading & Communality \\
\hline \multirow{7}{*}{$\begin{array}{l}\text { One- } \\
\text { dimensional } \\
\alpha=0.937\end{array}$} & $\begin{array}{l}\text { POS1 - My employer cares about my well- } \\
\text { being. }\end{array}$ & .897 & .804 \\
\hline & $\begin{array}{l}\text { POS } 2 \text { - My employer values my contributions } \\
\text { to its well-being. }\end{array}$ & .866 & .750 \\
\hline & $\begin{array}{l}\text { POS3 - My employer cares about my } \\
\text { opinions. }\end{array}$ & .862 & .742 \\
\hline & $\begin{array}{l}\text { POS4 - My employer considers my goals and } \\
\text { values. }\end{array}$ & .905 & .819 \\
\hline & $\begin{array}{l}\text { POS5 - My employer cares about my general } \\
\text { satisfaction at work. }\end{array}$ & .919 & .845 \\
\hline & $\begin{array}{l}\text { POS6 - My employer is willing to help me } \\
\text { when I need a special favor. }\end{array}$ & .779 & .607 \\
\hline & $\begin{array}{l}\text { POS7_inv - My employer shows very little } \\
\text { concern for me. }\end{array}$ & .752 & .565 \\
\hline \multicolumn{4}{|c|}{$\begin{array}{c}\text { Intention to leave a company } \\
\mathrm{KMO}=0.809 ; \text { Bartlett: } \chi^{2}=342.54 ; \text { dof }=6 ; \mathrm{p}<0.001 \\
\text { Variance explained }=82.98 \%\end{array}$} \\
\hline $\begin{array}{l}\text { Cronbach's } \\
\text { alpha }\end{array}$ & Item & Loading & Communality \\
\hline \multirow{4}{*}{$\begin{array}{l}\text { One- } \\
\text { dimensional } \\
\alpha=0.930\end{array}$} & $\begin{array}{l}\text { IL1 - I will probably look for a job at a different } \\
\text { company in the next year. }\end{array}$ & .938 & .881 \\
\hline & $\begin{array}{l}\text { IL2 - I will take steps during the next year to } \\
\text { secure a job at a different company. }\end{array}$ & .950 & .902 \\
\hline & $\begin{array}{l}\text { IL3_inv - I will be working at the same company } \\
\text { this time next year. }\end{array}$ & .857 & .735 \\
\hline & $\begin{array}{l}\text { IL4_inv - I will be with this company five years } \\
\text { from now. }\end{array}$ & .888 & .789 \\
\hline \multicolumn{4}{|c|}{$\begin{array}{c}\text { Well-being at work } \\
\mathrm{KMO}=0.850 ; \text { Bartlett: } \chi^{2}=471.91 ; \text { dof }=36 ; \mathrm{p}<0.001 \\
\text { Variance explained }=69.44 \%\end{array}$} \\
\hline $\begin{array}{l}\text { Cronbach's } \\
\text { alpha }\end{array}$ & item & Loading & Communality \\
\hline Positive & WB2 - Contented & .740 & .686 \\
\hline
\end{tabular}




\begin{tabular}{|c|c|c|c|}
\hline dimension & WB4 - Cheerful & .856 & .696 \\
\hline \multirow{2}{*}{$\alpha=0.892$} & WB5 - Enthusiastic & .983 & .826 \\
\hline & WB6 - Optimistic & .838 & .733 \\
\hline \multirow{5}{*}{$\begin{array}{l}\text { Negative } \\
\text { dimension } \\
\alpha=0.840\end{array}$} & WB8 - Uneasy & .811 & .584 \\
\hline & WB9 - Worried & .805 & .537 \\
\hline & WB10 - Depressed & .723 & .744 \\
\hline & WB11 - Gloomy & .768 & .736 \\
\hline & WB12 - Miserable & .845 & .710 \\
\hline
\end{tabular}


Table 3 Synthesis of Confirmatory Factor Analyses

\begin{tabular}{|c|c|c|c|}
\hline \multicolumn{4}{|c|}{$\begin{array}{c}\text { Presumption of employer benevolence } \\
\mathrm{SRMR}=.012 ; \mathrm{RMSEA}=.052 ; \mathrm{GFI}=.998 ; \mathrm{AGFI}=.977 ; \mathrm{TLI}=.994 \\
\chi^{2}=2.33 ; \mathrm{dof}=1 ; \mathrm{p}=0.127(3)\end{array}$} \\
\hline & Item & Loading & \\
\hline \multirow{4}{*}{ One-dimensional } & POB1 & .920 & \multirow{4}{*}{$\begin{array}{c}\text { Jöreskog's rho }=.89 \\
\text { cv rho }=.68\end{array}$} \\
\hline & POB2 & .909 & \\
\hline & POB3 & .576 & \\
\hline & POB4 & .841 & \\
\hline \multicolumn{4}{|c|}{$\begin{array}{c}\text { Perceived organizational support }(\text { POS }) \\
\text { SRMR }=0.029 ; \text { RMSEA }=0.068 ; \mathrm{GFI}=0.977 ; \mathrm{AGFI}=0.951 ; \mathrm{TLI}=0.983 \\
\chi^{2}=49.45 ; \mathrm{dof}=13 ; \mathrm{p}<0.001\end{array}$} \\
\hline & Item & Loading & \multirow{8}{*}{$\begin{array}{c}\text { Jöreskog's rho }=.94 \\
\text { cv rho }=.68\end{array}$} \\
\hline \multirow{7}{*}{ One-dimensional } & POS1 & .864 & \\
\hline & POS2 & .813 & \\
\hline & POS3 & .836 & \\
\hline & POS4 & .882 & \\
\hline & POS5 & .907 & \\
\hline & POS6 & .751 & \\
\hline & POS7_inv & .702 & \\
\hline \multicolumn{4}{|c|}{$\begin{array}{c}\text { Intention to leave a company } \\
\text { SRMR =.016; RMSEA }=.103 ; \mathrm{GFI}=.994 ; \mathrm{AGFI}=.938 ; \mathrm{TLI}=.982 \\
\chi^{2}=6.294 ; \mathrm{dof}=1 ; \mathrm{p}<0.05\end{array}$} \\
\hline & Item & Loading & \multirow{5}{*}{$\begin{array}{c}\text { Jöreskog's rho }=.92 \\
\text { cv rho }=.73\end{array}$} \\
\hline \multirow{4}{*}{ One-dimensional } & IL1 & .944 & \\
\hline & IL2 & .966 & \\
\hline & IL3_inv & .783 & \\
\hline & IL4_inv & .766 & \\
\hline \multicolumn{4}{|c|}{$\begin{array}{c}\text { Well-being } \\
\text { SRMR = .045; RMSEA }=.05 ; \text { GFI }=.976 ; \text { AGFI }=.956 ; \text { TLI }=.981 \\
\chi^{2}=53.83 \text { for } 24 \text { dof } p<0.001\end{array}$} \\
\hline Dimensions & item & Loading & \multirow{5}{*}{$\begin{array}{c}\text { Jöreskog's rho }=.88 \\
\text { cv rho }=.64\end{array}$} \\
\hline \multirow{4}{*}{ Positive dimension } & WB2 & .844 & \\
\hline & WB4 & .805 & \\
\hline & WB5 & .830 & \\
\hline & WB6 & .754 & \\
\hline \multirow{4}{*}{ Negative dimension } & WB8 & .578 & \multirow{4}{*}{$\begin{array}{c}\text { Jöreskog's rho }=.83 \\
\quad \mathrm{cv} \text { rho }=.50\end{array}$} \\
\hline & WB9 & .552 & \\
\hline & WB10 & .823 & \\
\hline & $\begin{array}{l}\text { WB11 } \\
\text { WB12 }\end{array}$ & $\begin{array}{l}.814 \\
.697\end{array}$ & \\
\hline
\end{tabular}


Table 4 Statistical significance of parameters (Student's test)

\begin{tabular}{lclc}
\hline Parameter & & & Estimation \\
\hline POS & $<---$ & Presumption of organizational benevolence & $.934^{* *}$ \\
Positive well-being & $<---$ & Presumption of organizational benevolence & $.253 \mathrm{~ns}$ \\
Negative well-being & $<---$ & Perceived organizational support & $-.447^{*}$ \\
Negative well-being & $<---$ & Presumption of organizational benevolence & $-.153 \mathrm{~ns}$ \\
Positive well-being & $<---$ & Perceived organizational support & $.469^{* *}$ \\
Intention to leave & $<---$ & Negative well-being & $.360^{* *}$ \\
Intention to leave & $<---$ & Positive well-being & $-.328^{* *}$ \\
\hline POB4 & $<---$ & Presumption of organizational benevolence & $.850^{* *}$ \\
POB3 & $<--$ & Presumption of organizational benevolence & $.598^{* *}$ \\
POB2 & $<---$ & Presumption of organizational benevolence & $.909^{* *}$ \\
POB1 & $<---$ & Presumption of organizational benevolence & $.912^{* *}$ \\
\hline IL4_inv & $<---$ & Intention to leave & $.783^{* *}$ \\
IL3_inv & $<---$ & Intention to leave & $.803^{* *}$ \\
IL2 & $<---$ & Intention to leave & $.942^{* *}$ \\
IL1 & $<---$ & Intention to leave & $.934^{* *}$ \\
\hline WB2 & $<---$ & Positive well-being & $.811^{* *}$ \\
WB4 & $<---$ & Positive well-being & $.780^{* *}$ \\
WB5 & $<---$ & Positive well-being & $.879^{* *}$ \\
WB6 & $<---$ & Positive well-being & $.814^{* *}$ \\
WB8 & $<---$ & Negative well-being & $.631^{* *}$ \\
WB10 & $<---$ & Negative well-being & $.792^{* *}$ \\
WB11 & $<---$ & Negative well-being & $.810^{* *}$ \\
WB12 & $<---$ & Negative well-being & $.731^{* *}$ \\
WB9 & $<---$ & Negative well-being & $.559^{* *}$ \\
\hline POS1 & $<----$ & Perceived organizational support & $.869^{* *}$ \\
POS2 & $<---$ & Perceived organizational support & $.812^{* *}$ \\
POS3 & --- & Perceived organizational support & $.843^{* *}$ \\
POS4 & Perceived organizational support & $.886^{* *}$ \\
POS5 & & $.897^{* *}$ \\
POS6 & & $.766^{* *}$ \\
POS7_inv & & $.679^{* *}$ \\
\hline & &
\end{tabular}

Note:

* Significant at $0.05 ; * *$ Significant at 0.01 